\title{
Development and Utilization of Female Labor Force in Rural Areas in Guizhou During Economic Transformation Period A Survey of 10 Villages in Guizhou in 2016
}

\author{
Zhuping Zhang ${ }^{1}$, Ziqing $\mathbf{L i}^{2}$ \\ ${ }^{1}$ Department of Economics, the International College of Guizhou University of Finance and Economics, Guizhou, China \\ ${ }^{2}$ Accounting Department, School of International Studies, Guizhou University of Finance and Economics, Guizhou, China
}

Email address:

916593424@qq.com (Zhuping Zhang),1427771626@qq.com (Ziqing Li)

\section{To cite this article:}

Zhuping Zhang, Ziqing Li. Development and Utilization of Female Labor Force in Rural Areas in Guizhou During Economic Transformation Period_- A Survey of 10 Villages in Guizhou in 2016. American Journal of Agriculture and Forestry. Vol. 6, No. 4, 2018, pp. 103-110. doi: 10.11648/j.ajaf.20180604.17

Received: June 25, 2018; Accepted: July 31, 2018; Published: August 29, 2018

\begin{abstract}
Under the background of national economic transformation, in order to make Guizhou's vast rural women labor force better adapt to economic and social development and change. We conducted a household survey to investigate the total number of female labor force in 800 households in 10 villages in the rural areas of Guizhou Province, a total of 1008 people. From the survey of rural women's labor force, the situation of the rural women's labor is stable, the family business is mainly engaged, and most of the outgoing business work is the company type, with the majority of the provincial housekeeping workers, the legal consciousness is generally weak. As a result of multi industry labor, per capita income is much higher than that of the whole country and Guizhou province.
\end{abstract}

Keywords: Rural Area, Female Labor Force, Development and Utilization, Guizhou

\section{Introduction}

As the national economic growth slows down, the momentum of economic growth is weak. The central government has put forward the idea of "steady growth, structural adjustment, reform and people's livelihood" to promote sound and rapid economic and social development. [1] And Guizhou, one of the most poverty-stricken provinces in China, in order to enter a well-off society with the whole country in 2020, only after catching up with the latter, accelerating the development of the economy and realizing the rapid development of the social and economic development of Guizhou, put forward the development strategy of "two plus one push", that is to speed up the development, accelerate the transformation and promote the leap of the economy and society. Development. Agriculture, rural areas and farmers are also the key factors that affect and restrict the goal of Guizhou's overall realization of a well-off society. It is in the background that the national economic growth is slowing down and the way of economic growth needs to be adjusted. It is of great theoretical and practical significance to investigate and study the development and utilization of rural women's labor resources in Guizhou. The analysis conclusion can provide reference for the relevant departments to understand the employment situation of rural women.

Text: as half the sky in the labor force, women play an increasingly important role in family life along with the development of economy and society. In family life, we should not only bear the responsibility of giving birth to children, but also bear the economic responsibility of family survival and development. In particular, since the reform and opening up, the improvement of the social status of the women, especially the rural women, has gone out of the house, leaving home to work outside and taking part in the social and economic construction. In order to know more specifically about the development and utilization of rural female labor in Guizhou, the employment situation of 800 households in 10 villages in rural areas of Guizhou in 2016 was investigated. The relevant information of the investigation is described as follows. 


\section{Investigation and Analysis of Rural Women Labor in Guizhou}

As half the sky in the labor force, women play an increasingly important role in family life along with the development of economy and society. In family life, we should not only bear the responsibility of giving birth to children, but also bear the economic responsibility of family survival and development. In particular, since the reform and opening up, the improvement of the social status of the women especially the rural women, has gone out of the house, leaving home to work outside and taking part in the social and economic construction. In order to know more specifically about the development and utilization of rural female labor in Guizhou, the employment situation of 800 households in 10 villages in rural areas of Guizhou in 2016 was investigated. The relevant information of the investigation is described as follows.

\subsection{The Basic Situation of Rural Women's Labor Resources Surveyed}

The survey involves 10 villages in 10 counties (districts) of nine states (cities) in Guizhou province. There are 80 rural households in each village, with a total of 800 rural families and 1008 rural households with female labor. The average number of households in each household is 1.61 / households in Wudang District, the least of which is that there are only 0.83 people in the Bao Bao Village in Nayong county [2].

From the age structure of women's labor (Table 1), the order of the proportion from high to low is $41-50,21-30,23.51 \%$, $31-40,19.94 \%, 51-60,61,61$ years of age, $6.75 \%, 20$ and below $3.47 \%$. According to the year of birth, the highest proportion of age 41-50 was calculated, mainly from the end of the $60 \mathrm{~s}$ to the first half of $70 \mathrm{~s}$, and the country had not yet implemented the population family planning policy at that time. As long as they had fertility, they wanted to live and make the highest proportion of the age segment. At the age of $21-30$, the proportion of the age group is also higher, due to the loosening of the national population family planning policy in the first half of the $80 \mathrm{~s}$ to the first half of $90 \mathrm{~s}$, in fact the change in the number of women and the distribution of the age structure. We can also see the changes in the national population and family planning policy.

In terms of the educational background of the female labor force (the degree of Education) (Table 1), the number of junior high school graduates is the most, accounting for $50.69 \%$, which accounts for more than half of the female labor force. This proportion reflects that the national policy is to encourage rural women to receive education; secondly, the number of primary school graduates is accounted for. The number of illiterate and literate people was $13.99 \%$, and the number of people who graduated from senior high school and above accounted for $6.85 \%$ in $28.47 \%$. The result shows that the degree of education for women in the vast rural areas of Guizhou has been greatly improved, not only by national policy, but also in the concept of education for women in rural areas. In terms of the comparison of village and village, the difference is very large. The order of the proportion of the number of women in junior middle school and above is $87.49 \%$, the village of Changqing is $84.68 \%$, the village of Jiangxi is $75.61 \%$, the village of Mai Zhen is $72.09 \%$, the village is $62.12 \%$, the village of Xiao Chang dam is $57.02 \%$, and the village of the water cave is $44.74 \%$, Chu Jia Shan village is $40 \%$, Zhenjiang village is $23.47 \%$, and early peace village is $23.14 \%$. The highest proportion of villages is 64.35 percentage points different from the lowest. This shows that although the national policy is supported by the education of women, Guizhou is a multi-ethnic minority province, and the attitude of each ethnic group to the education of women is different. The village with a high proportion of education is also a village with a higher level of per capita income.

From the marital status (Table 1), $87.7 \%$ of the female labor force of the female labor force is married, $8.43 \%$ of the female labor force is unmarried, the widowers are $1.49 \%$, and $0.99 \%$ of the female labor force divorced. This shows that the rural female labor force in Guizhou is still relatively heavy in the last few years once the female labor force is married. The per capita income of rural areas has been greatly improved, but the proportion of divorce is still not high, that is to say, the marital status is relatively stable. The divorce rate of Shui Dong village, Ping Chu village, Chu Jia Shan village, Lighthouse Village and Mai Yi village is even 5.

Table 1. Basic situation of female labor force of 800 households in 10 villages in Guizhou.

\begin{tabular}{|c|c|c|c|c|c|c|c|c|c|c|c|}
\hline & shuidong & pingchu & xiaoyangba & jiangxi & zhujiashan & dengta & changqing & baobaozhai & mairang & zhenjiang & ALL \\
\hline $\begin{array}{l}\text { 1. the number of households } \\
\text { surveyed }\end{array}$ & 80 & 80 & 80 & 80 & 80 & 80 & 80 & 80 & 80 & 80 & 800 \\
\hline $\begin{array}{l}\text { 2. female labor force } \\
\text { 3. age structure }\end{array}$ & 114 & 95 & 114 & 82 & 95 & 104 & 111 & 66 & 129 & 98 & 1008 \\
\hline 20 years and below $(\%)$ & & 1.05 & 3.51 & & 1.05 & 7.69 & 1.80 & 3.03 & 6.98 & 8.16 & 3.47 \\
\hline 21 - 30 years old $(\%)$ & 28.95 & 29.47 & 28.07 & 18.29 & 17.89 & 27.88 & 25.23 & 19.70 & 19.38 & 17.35 & 23.51 \\
\hline $31-40$ years old $(\%)$ & 8.77 & 32.63 & 14.04 & 29.27 & 14.74 & 22.12 & 22.52 & 16.67 & 15.50 & 27.55 & 19.94 \\
\hline $51-60$ years old $(\%)$ & 18.42 & 9.47 & 25.44 & 19.51 & 14.74 & 15.38 & 20.72 & 25.76 & 12.40 & 12.24 & 17.16 \\
\hline Above 61 years of age $(\%)$ & 9.65 & 7.37 & 14.04 & & 9.47 & & 5.41 & 6.06 & 10.08 & 2.04 & 6.75 \\
\hline $\begin{array}{l}\text { 4. educational background } \\
\text { College and above }(\%)\end{array}$ & & & & 1.22 & & 2.88 & 5.41 & & 2.33 & & 1.29 \\
\hline High school (\%) & 3.51 & 2.11 & 6.14 & & 3.16 & 7.69 & 4.50 & 3.03 & 17.05 & 3.06 & 5.56 \\
\hline Junior middle school (\%) & 41.23 & 21.05 & 50.88 & 74.39 & 36.84 & 76.92 & 74.77 & 59.09 & 52.71 & 20.41 & 50.69 \\
\hline Primary school (\%) & 34.21 & 21.05 & 36.84 & 17.07 & 46.32 & 10.58 & 14.41 & 24.24 & 24.03 & 55.10 & 28.47 \\
\hline
\end{tabular}




\begin{tabular}{llllllllllll}
\hline & shuidong & pingchu & xiaoyangba jiangxi & zhujiashan & dengta & changqing & baobaozhai & mairang & zhenjiang & ALL \\
\hline Illiteracy and literacy (\%) & 21.05 & 55.79 & 6.14 & 7.32 & 13.68 & 1.92 & 0.90 & 13.64 & 3.88 & 21.43 & 13.99 \\
5. marital status & & & & & & & & & & & \\
Unmarried (\%) & 12.28 & 6.32 & 7.02 & 4.88 & 9.47 & 13.46 & 9.01 & 7.58 & 14.73 & 10.20 & 8.43 \\
Married (\%) & 87.72 & 92.63 & 87.72 & 92.68 & 87.37 & 85.58 & 87.39 & 84.85 & 84.50 & 87.76 & 87.70 \\
Divorce (\%) & & & 0.88 & 1.22 & & & 0.90 & 7.58 & & 2.04 & 0.99 \\
Widowhood (\%) & & 1.05 & 4.39 & 1.22 & 3.16 & 0.96 & 2.70 & & 0.78 & \\
\hline
\end{tabular}

\subsection{The Current Employment Situation of Women Labor Force in Rural Areas and the Industry They Are Engaged in}

From the current employment situation of female labor in Guizhou (Table 2), most of the female labor force is still mainly engaged in family management, accounting for $60.61 \%$; the second is the employment of $17.56 \%$, and the number of odd jobs is not few, accounting for $13.69 \%$, and the other $6.35 \%$, and only $1.79 \%$. This shows that Guizhou women labor is still more diligent, as long as there is a chance of employment, or willing to find a living way to make a living, rather than doing nothing at home one day. Compared to the village and village, the number of families engaged in family management is higher than the average value of 10 villages: Water Cave Village $71.05 \%$, Jiangxi village $60.98 \%$, Chu family village $74.74 \%$, Bao Zhai village $65.15 \%$ and Zhenjiang village $62.24 \%$ five villages. In the village, the average number of employees employed is higher than the average of 10 villages: $38.95 \%$ in the village of Ping Chu, $20.18 \%$ in small field dam village, $23.08 \%$ in Lighthouse Village, $18.18 \%$ in Bao Zhai village and $22.48 \%$ in five villages in maitu village. This shows that with the rapid progress of industrialization, urbanization and agricultural modernization in Guizhou, the number of industrial enterprises, service enterprises and rural enterprises has been greatly increased. At the same time, the demand for labor and employment has increased greatly, which has enabled the vast number of female labor force in rural areas to have employment opportunities and stable employment. According to the proportion of odd jobs in each village, the villages above the average value of 10 villages are: Jiangxi village $21.95 \%$, lighthouse.

From the field of rural women's labor force (Table 2), the first is that the planting industry accounts for $54.46 \%$; the second is that the other sectors account for $24.01 \%$; the second is that the industry and the catering service account for $6.05 \%$; the next order is the business $3.37 \%$, the construction industry $2.38 \%$, the animal husbandry and aquaculture industry $2.08 \%$, the transportation $1.29 \%$ and the forestry $0.30 \%$. This shows that the cultivation of the planting industry can make the family survive. Only the family's survival has no worries about the development of the family. As for the other industries with high female labor force, it is mainly the higher income level than the industry, the catering service industry, the business and so on, which makes the employment of the industry more female. In terms of the comparison between the villages, the villages with high employment ratio in other industries are: $50.53 \%$ in the village of Ping Chu, $25.61 \%$ in Jiangxi village, $48.08 \%$ in Lighthouse Village and $24.81 \%$ in four villages in maitu village. This shows that the other industries are higher than other industries, and as the economic and social development, the number of women employed in this other industry will be more and more.

Table 2. Current employment situation of rural female labor force and mainly engaged in industry.

\begin{tabular}{|c|c|c|c|c|c|c|c|c|c|c|c|}
\hline & shuidong & pingchu & xiaoyangba & jiangxi & zhujiashan & dengta & changqing & baobaozhai & mairang & zhenjiang & ALL \\
\hline \multicolumn{12}{|l|}{$\begin{array}{l}\text { 1. current employment } \\
\text { situation }\end{array}$} \\
\hline $\begin{array}{l}\text { Engaged in family } \\
\text { management (\%) }\end{array}$ & 71.05 & 44.21 & 53.51 & 60.98 & 74.74 & 59.62 & 60.36 & 65.15 & 56.59 & 62.24 & 60.61 \\
\hline $\begin{array}{l}\text { Employment of stable } \\
\text { employment }(\%)\end{array}$ & 10.53 & 38.95 & 20.18 & 12.20 & 14.74 & 23.08 & 7.21 & 18.18 & 22.48 & 8.16 & 17.56 \\
\hline Odd jobs $(\%)$ & 3.51 & 6.32 & 13.16 & 21.95 & 2.11 & 16.35 & 18.02 & 13.64 & 16.28 & 26.53 & 13.69 \\
\hline Other $(\%)$ & 14.91 & 5.26 & 7.89 & 4.88 & 8.42 & & 10.81 & 3.03 & 4.65 & 1.02 & 6.35 \\
\hline \multicolumn{12}{|l|}{$\begin{array}{l}\text { 2. mainly engaged in } \\
\text { industry }\end{array}$} \\
\hline Planting industry (\%) & 73.68 & 44.21 & 50.88 & 57.32 & 67.37 & 26.92 & 50.45 & 62.12 & 58.91 & 54.08 & 54.46 \\
\hline Forestry $(\%)$ & & & 2.63 & & & & & & & & 0.30 \\
\hline $\begin{array}{l}\text { Animal husbandry and } \\
\text { aquaculture (\%) }\end{array}$ & 1.75 & 1.05 & 1.75 & & 4.21 & & & 4.55 & 2.33 & 6.12 & 2.08 \\
\hline Industry $(\%)$ & 1.75 & 2.11 & 9.65 & 4.88 & 4.21 & 16.35 & 8.11 & 3.03 & 6.20 & 2.04 & 6.05 \\
\hline Transport industry (\%) & 0.88 & & 4.39 & & 3.16 & 2.88 & 0.90 & & & & 1.29 \\
\hline Business (\%) & 2.63 & 1.05 & 4.39 & 2.44 & 1.05 & 2.88 & 9.91 & 3.03 & 1.55 & 4.08 & 3.37 \\
\hline $\begin{array}{l}\text { Catering service industry } \\
(\%)\end{array}$ & 5.26 & & 4.39 & 4.88 & 2.11 & 2.88 & 10.81 & 19.70 & 5.43 & 9.18 & 6.05 \\
\hline Other industries (\%) & 10.53 & 50.53 & 17.54 & 25.61 & 15.79 & 48.08 & 14.41 & 7.58 & 24.81 & 23.47 & 24.01 \\
\hline
\end{tabular}




\subsection{Rural Female Labor Force Current Employment Location and Province}

In terms of the current employment location of the rural female labor force in Guizhou (Table 3), $75.69 \%$ of the female labor force is employed in the township, and $13.79 \%$ of the female labor force goes to the province outside the province. The number of employment in the county and the county is not much, $5.95 \%$ and $4.56 \%$, and no one is employed abroad. This shows. If the employment of women outside the country is recognized as a migrant worker, this part of the population accounts for $24.30 \%$ (1/4) of the rural women's labor force, and the proportion of the provincial labor and migrant workers is $10.51: 13.79$, that is to say, the employment of migrant workers outside the province is the main job. [3] In terms of the comparison between villages and villages, there are 6 villages, namely, water cave village, Ping Chu village, small field dam village, Chu Jia village, bag village village and maitu village, and 4 villages of Jiangxi village, Lighthouse Village, Changqing village and Zhenjiang village, which are mainly employed in the province. This result should be the change brought by Guizhou's accelerating industrialization.

From the distribution of the total employment area of rural female labor force in Guizhou, $86.51 \%$ of the province and $13.49 \%$ of the province's labor force accounted for the total employment area. Among the $86.51 \%$ rural female labor forces in the province, $10.51 \%$ of the female labor force left the country to the provinces to work in the province. There are $76 \%$ of the rural women labor left behind in the rural areas. This part is the left behind women we usually say, and the female labor force of $13.49 \%$ migrant workers outside the province has gone to 8 . Province (city), the number of provinces (cities) with relatively large number of provinces (cities) have: Zhejiang accounted for $6.35 \%$, Guangdong accounted for $3.47 \%$ and Guangxi $1.39 \%$, the remaining 5 provinces (cities) to work for employment of less than one percent of the number of provinces (cities) are more developed in the province (city). As far as the village situation is concerned, the water cave village is mainly to Guangdong and Guangxi. The village of Ping Chu is mainly to Zhejiang and Guangdong, the village of Xiao Chang dam mainly goes to Jiangxi, the village of Chu Jia mountain and the lighthouse village all go to Zhejiang, Jiangxi village, Changqing village and Bao Bao Village are mainly to Zhejiang, Zhenjiang village is mainly to Guangdong. In fact, for rural women labor, where to go to work do not matter, to consider mainly: the first is whether or not with the husband (or boyfriend) together; two is to find work can make money; three is easy to find work; four is the technical threshold of employment, labor intensity to adapt themselves.

Table 3. Current employment locations and provinces of rural female labor force.

\begin{tabular}{|c|c|c|c|c|c|c|c|c|c|c|c|}
\hline & shuidon & pingchu & xiaoyangba & jiangxi & zhujiashan & dengta & changqing & baobaozhai & mairang & zhenjiang & ALL \\
\hline \multicolumn{12}{|l|}{ 1. place of employment } \\
\hline Within the town $(\%)$ & 87.72 & 55.79 & 57.02 & 71.95 & 83.16 & 96.15 & 67.57 & 71.21 & 96.12 & 62.24 & 75.69 \\
\hline In the rural county $(\%)$ & 1.75 & 5.26 & 8.77 & 1.22 & 7.37 & 2.88 & 11.71 & 7.58 & 1.55 & 12.24 & 5.95 \\
\hline $\begin{array}{l}\text { In the province of the county } \\
(\%)\end{array}$ & 1.75 & 1.05 & 8.77 & 14.63 & & & 10.81 & 3.03 & & 7.14 & 4.56 \\
\hline Outside the province $(\%)$ & 8.77 & 37.89 & 25.44 & 12.20 & 9.47 & 0.96 & 9.91 & 18.18 & 2.33 & 18.37 & 13.79 \\
\hline \multicolumn{12}{|l|}{ Abroad $(\%)$} \\
\hline \multicolumn{12}{|l|}{$\begin{array}{l}\text { 2. provinces where } \\
\text { employment is located }\end{array}$} \\
\hline guizhou (\%) & 90.35 & 62.11 & 78.07 & 87.80 & 90.53 & 99.04 & 90.09 & 81.82 & 97.67 & 81.63 & 86.51 \\
\hline zhejiang (\%) & & 24.21 & 3.51 & 7.32 & 9.47 & 0.96 & 6.31 & 15.15 & 0.78 & 3.06 & 6.35 \\
\hline guangdong (\%) & 4.39 & 11.58 & 2.63 & 3.66 & & & 1.80 & & & 11.22 & 3.47 \\
\hline guangxi (\%) & 0.88 & & 11.40 & & & & & & & & 1.39 \\
\hline yunnan (\%) & 4.39 & & 0.88 & 1.22 & & & & 1.52 & & & 0.79 \\
\hline fujian $(\%)$ & & 2.11 & & & & & 0.90 & & & 2.04 & 0.50 \\
\hline henan $(\%)$ & & & & & & & & & 0.78 & 2.04 & 0.30 \\
\hline jiangsu (\%) & & & & & & & & 1.52 & & & 0.10 \\
\hline
\end{tabular}

\subsection{The Way of Employment of Rural Female Labor Force and the Signing of Labor Contract by Employment}

In the 10 villages of Guizhou, the employment approach of female labor (Table 4), first of all, is self employed, accounting for $56.94 \%$; the second is the relatives and the old townships, accounting for $27.08 \%$; again, they are looking for work in the labor market, accounting for $13.59 \%$; finally, the government help contact, social intermediary introduction and school introduction three items account for only $2.38 \%$.
In fact, self employment is a very broad concept, it can be home to be engaged in planting, aquaculture, and can also be at home to carry out family management or independent entrepreneurship. According to the survey results of the $75.69 \%$ of the employment sites in this town, it is known that the motivation of self employed women is basically in this town. 3 From the comparison of the villages, more than 10 villages have more than 10 villages: Water Cave Village (73.68\%), Ping Chu village (61.05\%), Jiangxi Village (75.61\%), Lighthouse Village (100\%), Changqing Village 
(80.18\%), Bao Bao Village (69.70\%) and Zhenjiang Village $(61.22 \%) 7$ villages. Compared with the total number of women, the number of migrant workers is still a minority. However, with the industrialization of Guizhou and the further acceleration of the pace of urbanization, there are many Guizhou mountains, less land, less water and less field, which will make the proportion of female laborers independent entrepreneurs and migrant workers more than the proportion of family management.

From the case of employment and labor contracts in the female labor force (Table 4), the female labor force, which has signed labor employment contracts, accounts for $10.42 \%$ of the total number of women. We compare the results with the result of the stable employment of $17.56 \%$ of the employment in the current employment situation, and found that several village female labor forces are subject to the result. The proportion of employment and signing labor contracts is very high or high, such as: Jiangxi village, Lighthouse Village, Changqing village, Mai Village and Zhenjiang village 5 villages. Although there are several female labor force employed in several villages, the proportion of employment contracts is not high, such as Shui Dong village, Ping Chu village, Chu Jia Shan village and Bao Zhai village. Because signing labor employment contract is not only a respect for laborers, but also a protection for workers' rights and interests. Therefore, we need to strengthen the education of rural women's labor force in Guizhou, so that they can understand how to protect their legitimate rights and interests with legal weapons.

Table 4. Employment channels for rural female labor force and employment contract signing.

\begin{tabular}{|c|c|c|c|c|c|c|c|c|c|c|c|}
\hline & shuidong & pingchu & xiaoyangba & jiangxi & zhujiashan & dengta & changqing & baobaozhai & mairang & zhenjiang & ALL \\
\hline \multicolumn{12}{|l|}{ 1ways of employment } \\
\hline $\begin{array}{l}\text { Introduction of relatives and } \\
\text { townships }(\%)\end{array}$ & 21.05 & 32.63 & 65.79 & 15.85 & 8.42 & & 19.82 & 9.09 & 60.42 & 16.33 & 27.08 \\
\hline $\begin{array}{l}\text { Find yourself in the labor } \\
\text { market (\%) }\end{array}$ & 2.63 & 6.32 & 22.81 & 7.32 & 55.79 & & & 21.21 & 6.20 & 21.42 & 13.59 \\
\hline Government assistance (\%) & & & 0.88 & & 1.05 & & & & 3.88 & 1.02 & 0.79 \\
\hline $\begin{array}{l}\text { Introduction of social } \\
\text { intermediary organizations (\%) }\end{array}$ & 1.75 & & 0.88 & 1.22 & & & & & & & 0.40 \\
\hline School introduction $(\%)$ & 0.88 & & 1.75 & & 1.05 & & & & 6.20 & & 1.19 \\
\hline $\begin{array}{l}\text { Self employment }(\%) \\
\text { 2. if employed, and to sign a } \\
\text { labor contract }\end{array}$ & 73.68 & 61.05 & 7.89 & 75.61 & 33.68 & 100.00 & 80.18 & 69.70 & 23.26 & 61.22 & 56.94 \\
\hline Signing a contract $(\%)$ & 0.88 & & 12.28 & 12.20 & 1.05 & 28.08 & 16.22 & 6.06 & 18.60 & 9.18 & 10.42 \\
\hline No contract (\%) & 99.12 & 100.00 & 87.72 & 87.80 & 98.95 & 76.92 & 83.78 & 93.94 & 81.40 & 90.82 & 89.58 \\
\hline
\end{tabular}

\subsection{The Training of Rural Women's Labor Force}

We know that the main driving force for promoting economic development is technological progress, and the source of the advancement of technology is the improvement of the quality of the labor force, and the improvement of the quality of the labor force is no more than three ways: one is to improve the quality of labor through educational education, which is accomplished mainly through school education; and the two is through "dry school", that is, In the course of career, the quality of the labor force is improved through the accumulation of experience and the way of improving the work; three is to improve the quality of the labor force through skill training, that is, to take part in a variety of training classes. This part mainly investigates the training and training of female labor force in 10 villages in Guizhou, which is organized by government.

In the 10 village women's labor force to accept agricultural technology training (Table 5), 10.12\% of the female labor force received agricultural training, and nearly $90 \%$ of the female labor force did not receive training. The situation in the villages is very different. There are water cave village, Ping Chu village, Chu Jia mountain village, Bao Zhai village and maitu village 5 village women's labor force did not receive any training on agricultural technology. The villages with better agricultural skills training than the female labor force are: Jiangxi Village (73.17\%), Changqing Village $(20.72 \%)$ and Zhenjiang Village (11.22\%). This shows that there is a great difference between villages and villages. The villages with relatively high proportion of agricultural technology training are also villages with relatively high income level. This requires the government's relevant agricultural education and training departments to hold more training in agricultural technology knowledge in villages with low proportion of agricultural technology training. For villages with relatively high proportion of agricultural technology training, they should organize more targeted agricultural skills training according to market demand for agricultural products.

In regard to the training of rural female labor force in the field of employment training (Table 5), the average number of $9.42 \%$ female workers in 10 villages was trained for employment. Out of the job training is the government's training for the labor force that has the needs of migrant workers and jobs. In combination with table 3, when we recognize the female workers who work outside the country as migrant workers, the female labor is $38.78 \%$, which is relatively high.. In the case of the employment training in each village, the village with a higher proportion of women's labor force in the village has been accepted by the women in the village of Jiangxi (12.20\%), the Lighthouse Village $(20.19 \%)$, the Changqing Village $(27.93 \%)$, the village 
(13.18\%) and the village of Zhenjiang (12.24\%), and the 5 villages in the village. The proportion of industry training is very low, namely: Water Cave Village, Ping Chu village, small field dam village (1.75\%), Chu Jia mountain village
(1.05\%) and Bao Bao stockaded village (1.52\%), which hope to attract the attention of relevant departments of the local government. With the further acceleration of urbanization in Guizhou, the number of migrant workers will also increase.

Table 5. The training of rural women's labor force.

\begin{tabular}{|c|c|c|c|c|c|c|c|c|c|c|c|}
\hline & shuidong & pingchu & xiaoya & jiangxi & zhujiashan & dengta & changqing & baobaozhai & mairang & zhenjiang & $\mathbf{A L L}$ \\
\hline \multicolumn{12}{|c|}{$\begin{array}{l}\text { 1. to receive training in } \\
\text { Agricultural Technology }\end{array}$} \\
\hline Acceptance $(\%)$ & & & 1.75 & 73.17 & & 5.77 & 20.72 & & & 11.22 & 10.12 \\
\hline Not accepted $(\% 0$ & 100.00 & 100.00 & 98.25 & 26.83 & 100.00 & 94.23 & 79.28 & 100.00 & 100.00 & 88.78 & 89.88 \\
\hline \multicolumn{12}{|c|}{ 2. training for outgoing training } \\
\hline Acceptance $(\%)$ & & & 1.75 & 12.20 & 1.05 & 20.19 & 27.93 & 1.52 & 13.18 & 12.24 & 9.42 \\
\hline Unaccepted (\%) & 100.00 & 100.00 & 98.25 & 87.80 & 98.95 & 79.81 & 72.07 & 98.48 & 86.82 & 87.76 & 90.58 \\
\hline
\end{tabular}

\subsection{The Cumulative Employment Days and Cash Income of Female Labor Force in Rural Areas}

The investigation of the employment situation of female labor force in the rural areas should eventually be implemented and reflected in the employment time and labor remuneration. In terms of the number of days of employment for 1-12 months of female labor in the 10 villages of Guizhou in 2015 (Table 6), due to the existence of the Spring Festival and the traditional festivals of ethnic minorities, the actual number of employment days of rural women's labor force has been greatly affected. From the results of the survey, $64.68 \%$ of women's labor force employment days are between 91-180 days and $29.86 \%$ of the employment days of women's labor force are between 31-90 days, and 3.57\% of the women's labor employment days are between 1-30 days and 1.88\% of the women's labor force is not employed. As far as the specific circumstances of each village are concerned, there are many ethnic villages, such as the Miao village, the Dong village village, the Buyi village and the village of the people in the village. The employment habits of the villages are different. The number of women's labor employment days is 91 days ( 3 months) more than the average of 10 villages. (95.61\%), Jiangxi Village (69.51\%), Changqing Village $(68.47 \%)$, Bao Zhai village $(89.39 \%)$, Mai Yu Village $(77.52 \%)$ and Zhenjiang Village $(76.53 \%) 6$ villages. The number of women employed in labor force accounted for more than $50 \%$ days in 31-90 days (1-3 months): Ping Chu village (50.53\%) and Lighthouse Village (61.54\%). [4] In general, most of the rural women's labor force, whether they are engaged in the family business or out of work, still needs to make money for the survival and employment of the family.

In 1-12 months of 2015, the employment cash income of women's labor in 10 villages in Guizhou was found (Table 6). It was necessary to explain that $51(5.06 \%)$ of the 1008 rural women's labour force in the 10 villages were not reported in cash, mainly due to their family business or job employment. The industry did not receive cash income during the survey period, so it did not fill in cash receipts. When analyzing the cash income of rural women's labor force, this part of women's labor force is also eliminated. On the 957 (94.94\%) rural women's labor force, the per capita cash income of 1-12 months of 2015 was 12672.24 yuan, which was higher than that of the income level: the per capita cash income was 17676.6 yuan in Chu Jia mountain village, and the per capita cash income was 13263.1 yuan in Lighthouse Village, and the per capita cash income was 17699.5 yuan in Changqing village. The average cash income per capita in Zhai village is 15326.7 yuan, and the average per capita cash income in Mai Village is 16903.4 yuan in 5 villages. The lowest per capita cash income of women labor force is 6908.7 yuan in Shui Dong village. The absolute cash income difference between the highest per capita cash income (the highest Village) and the lowest Village (Shui Dong Village) is 10790.8 yuan. The lowest per capita cash income village is only $39.03 \%$ of the highest per capita cash income of the village, less than half. This shows that the income gap between the village and the village is very large, which is related to the local humanistic and geographical environment of the village, but also with the promotion of the promotion of local industrialization and urbanization.

According to the statistics published by the Statistics Bureau of China in 2016, the per capita disposable income of rural resident residents in 1-12 months is 12363 yuan, and the per capita disposable income of rural residents in Guizhou province is 8090 yuan. The per capita income of 10 villages in Guizhou has been compared with the national level (15080 yuan), which is more than the national level (12363 yuan). It is $21.98 \%$ higher than the Guizhou level ( 8090 yuan) $86.40 \%$. The annual cash income of the 10 villages in Guizhou was generally higher than the per capita disposable income level of the rural residents in the whole country and Guizhou Province in 2016. There may be the following reasons. One is that the local non agricultural self-employed and outgoing women's labor income has increased, the productive input increases; and the two is the poverty alleviation and rural production in Guizhou. The restructuring of the industry has increased. 
Table 6. Cumulative employment days and cash income of rural female labor force.

\begin{tabular}{|c|c|c|c|c|c|c|c|c|c|c|c|}
\hline & shuidon & pingchu & xiaoyangba & jiangxi & zhujiashan & dengta & changqing & baobaozhai & mairang & zhenjiang & ALL \\
\hline \multicolumn{12}{|c|}{$\begin{array}{l}\text { The cumulative number of days } \\
\text { of employment in } 1.1-12 \text { months }\end{array}$} \\
\hline 0 days (no employment) (\%) & 1.75 & 11.58 & & & & 0.96 & 2.70 & & & 2.04 & 1.88 \\
\hline $1-180$ days $(\%)$ & 2.63 & 57.90 & 52.63 & 30.49 & 43.16 & 61.54 & 28.83 & 10.61 & 22.49 & 21.43 & 33.43 \\
\hline $181-360$ days $(\%)$ & 95.61 & 30.53 & 47.37 & 69.51 & 56.84 & 37.50 & 68.47 & 89.39 & 77.52 & 76.53 & 64.68 \\
\hline \multicolumn{12}{|l|}{ 2.1-12 monthly cash income } \\
\hline Unfilled income (\%) & 5.26 & 8.42 & & & & 0.96 & 2.70 & 45.54 & & 3.06 & 5.06 \\
\hline $\begin{array}{l}\text { Per capita income of women's } \\
\text { labor (yuan) }\end{array}$ & 8221.4 & 9502.3 & 14485.6 & $\begin{array}{l}13250 . \\
4\end{array}$ & 21035.2 & $\begin{array}{l}15783 . \\
1\end{array}$ & 21062.4 & 18238.8 & 20115.0 & 8863.8 & 15080 \\
\hline
\end{tabular}

\section{Conclusion and Comments}

The survey involved 10 villages in 10 counties (districts) of nine prefectures (cities) in Guizhou Province, 80 farmers in each village, and 1008 women in rural families. [6] From the age structure of the rural women's labor, the order from high to low is $41-50,29.17 \%, 21-30,23.51 \%, 31-40,19.94 \%$, $51-60,17.16 \%, 6.75 \%$, and $6.75 \%$, and below 20 years of $3.417 \%$. From the academic structure of the rural women's labor, the order from high to low is $50.69 \%$ in junior middle school, $28.47 \%$ in primary school, $13.99 \%$ in illiteracy and literacy, and $6.85 \%$ in high school and above. The age structure is $41-50$ years old, and the educational structure is junior high school graduates. From the survey of marital status of rural female labor force, $87.70 \%$ were married, $8.43 \%$ were unmarried, $1.49 \%$ were widowed, and $0.99 \%$ divorced. It shows that the family marital status in rural areas of Guizhou is relatively stable.

From the current employment situation in the rural women's labor force, $60.61 \%$ of them are engaged in family management, and many of them are employed steadily, accounting for $17.56 \%$, and a certain proportion of odd jobs, which is $13.69 \%$. From the specific industry, the most is the planting industry, accounting for $54.56 \%$; the second is the other industries, accounting for $24.01 \%$; the second is the family industry, accounting for $6.05 \%$ and the catering services, accounting for $6.05 \%$; the proportion of the remaining industries is not high.

From the current employment location of the rural female labor force and the province (city) of the employment, $86.51 \%$ of the female labor force employed in Guizhou Province, and $13.49 \%$ of the female labor force went out to work in 8 provinces (cities) such as Zhejiang, Guangdong and Guangxi, which accounted for 7 of the $86.51 \%$ rural women labor in the province of Guizhou. 5.69\% of the female labor force in this township employment, accounting for $5.95 \%$ of the female labor in this county outside the county employment in the county, accounting for $4.56 \%$ of the female labor in the province outside the province. This result is the change brought by Guizhou's acceleration of industrialization and urbanization [6].

From the survey of the employment of rural female labor force and employment contract, it is mainly self-employed, accounting for $56.94 \%, 27.08 \%$ of their relatives or townships, and $13.59 \%$ of their work in the labor market. In fact, in recent years, with Guizhou increasing investment in various industries and increasing the strength of attracting investment, Guizhou is in the accelerating period of new industrialization and urbanization, and many rural female labor forces are not used to work outside. Only in this county or in this township can the migrant workers be separated from the countryside. [7] From the situation of employment and signing labor contracts, the proportion of some villages to sign contracts is high and the proportion of some villages to sign contracts is low, and the relevant departments are expected to strengthen the legal knowledge education in this respect.

In the case of the training of the rural women's labor force, the number of agricultural technical training received by government organizations accounted for $10.12 \%$ of the total number of respondents, and the per capita employment training received by government organizations accounted for $9.42 \%$ of the number of respondents, although the two items were not high, but the government departments have done their best to achieve it. Result.

In the end, from the survey of the total employment days and cash income of the rural women's labor force, there are $33.43 \%$ of the total employment days of female labor in $1-180$ days, and $64.68 \%$ of the total employment days of the female labor force are in 181-360 days. 957 rural female workers with cash income have been reported. The per capita cash income of $94.94 \%, 1$ to December is 15080 yuan, which is higher than the national average income level of $21.98 \%$, which is higher than the average level of rural income in Guizhou province by $86.40 \%$.

\section{Discussion}

Through the summary of this survey, I believe that, in order to make Guizhou's rural women labor force, in Guizhou to accelerate the process of accelerating industrialization, urbanization and agricultural modernization, better adapt to the economic and social development and change, the following suggestions are put forward [9]:

First, under the guidance of the government, give full play to the radiation and driving function of the central town, create more employment opportunities for the rural female labor force, and truly form the urban and rural integration pattern of rural areas driven by cities and towns with industrial drive, 
mutual promotion and common development. [10]

The two is the government departments concerned to innovate labor export mechanism, improve the management and service system, expand the field and scale of rural women labor labor export, widen the rural women's labor force to increase income free. [8]

Three, in the process of promoting industrialization and urbanization, the expansion of urbanization led to the loss of land by a large number of farmers. [5] As a government department, it is necessary to increase the skill training for the female labor of the lost land. The rural female labor force after the loss of land can be turned out, the social security can be stable, and the income can be increased.

\section{References}

[1] New changes in the mode of transfer of rural labor force under the background of Zhang Jian's equal new urbanization (J), Anhui agricultural science 2015.5.

[2] Research on employment characteristics of rural female labor force such as Zhang WW [J] research world 2012.6.

[3] Hou MZ, Kuang AP. Transfer of rural women's labor force and human capital investment in China [J]. agricultural economy, 2004 (5): 20-21.

[4] Yang EF. Thoughts on the situation of rural female labor force [J]. China Women's transport, 2004 (10): 28—29.

[5] Chen F. Countermeasures for the development of Western women's human resources [J]. Journal of Yunnan University of Nationalities (PHILOSOPHY AND SOCIAL SCIENCES EDITION), 2003 (5): 25-29.

[6] Li M, Zeng M. research on the development of female human resources in Guizhou [J]. Journal of the Party School of Guizhou provincial Party committee, 2006 (1): 58-59.
[7] Wang FX, Li YX, Wang JX. On the diversification strategy of rural surplus labor transfer in China, $[\mathrm{J}]$. Economic Forum, 2007, (23): 128.130

[8] Zhang HY. The current situation and Countermeasures of Chinese women's employment [J]. frontier economy and culture, 2006 (9).

[9] Chen H. Research on human capital and non-agricultural employment of rural labor force [D]. Nanjing: Nanjing Agricultural University, 2007.

[10] Liu Y and Li YY: (analysis of gender differences in informal employment of rural migrant workers in cities, "China rural economy" 2007 twelfth issue).

\section{Biography}

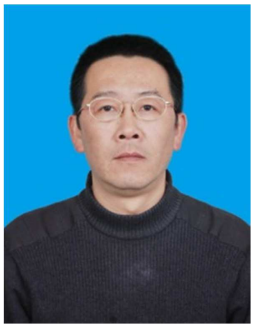

Zhuping Zhang (1962 -), associate professor of Guizhou University of Finance and economics; research area: Development Economics and rural economic development

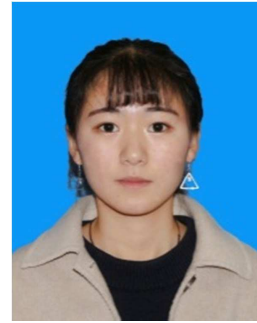

Ziqing Li (1999-) student of Guizhou University of Finance and Economics 